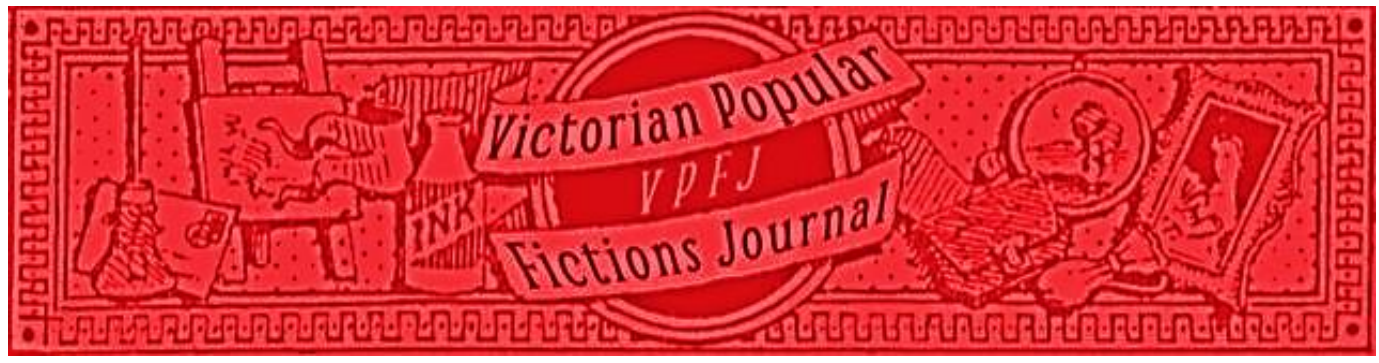

\title{
Wilkie Collins, Lo scrigno di Mr Wray, ovvero la maschera e il mistero. [Mr Wray's Cashbox] Edited with an Introduction by Mariaconcetta Costantini. Translated by Emilia Carmen Cavaliere. Rome: Libreria Croce, 2019, 192 pp. € 16,90. ISBN: 88-6402-371-2 EAN: 9788864023717
}

\author{
Reviewed by Francesca Vinci
}

Wilkie Collins was passionate about Italy, the Italian language and population, as his father William was. Together with his family, William moved to Italy in 1836 "to experience Italian landscape, art, and architecture at first hand and to paint Italian scenes" (Pykett 2005). Their two-year sojourn gave the young Collins a precious chance to learn to speak and write Italian, to discover the local culture and to become acquainted with several local artists. "I had learned more in Italy, which has since been of use to me, among the pictures, the scenery and the people, than ever I learnt at school", he wrote later in life (Ackroyd 2012).

Collins would have been pleased to learn that many Italian translations of his books have been produced in the last century and a half. Since 1884, when the first Italian translation of Heart and Science appeared (Heart and Science was the first of all his works translated into Italian), Collins's 'dream country' has indeed been paying homage to him. Most of his novels have been translated and published, some of them more than once. The Moonstone (1868), for example, has been translated fourteen times, from 1870 to 2016. Similarly, The Woman in White has been translated into Italian ten times from the early 1930s up to 2018. Interestingly, many Italian translations have appeared in the new millennium, either for the first time or the umpteenth time, probably encouraged by the growing scholarly attention for Collins both in England and abroad. Among them, it is worth remembering Antonina (2012), The Woman in White $(2015,2018)$, No Name (2015, 2016), Basil (2002, 2017), Armadale (2001, 2016), The Moonstone (2000, 2001, 2004, 2013, 2016), Man and Wife (2004, 2016, 2017), The Law and the Lady (2000, 2016, 2018), My Lady's Money (two translations in 2018, one published by Edizioni Croce and one by Landscape Books), The Haunted Hotel (2002, 2016), A 
Rogue's Life (2006), No Thoroughfare (2003), The Fallen Leaves (2005, 2018, 2019), The Black Robe (2003, 2018), The Guilty River (2002, 2018, 2019). Some other novels, such as The New Magdalen, The Two Destinies, Heart and Science, The Evil Genius and The Legacy of Cain have not been translated again since their first Italian publication in the late nineteenth century. Together with their twentieth- and twenty-first-century translations mentioned above, all these works prove the great success of Collins's production in the country he learned to love as a boy, and where he returned four times later in life.

Starting from the nineteenth century, Italian literature has been influenced by Collins's fiction. Most appealing to Italian writers were his sensational plots, his exploration of the human psyche (also evident in his experiments with multiple points of view), the Gothic atmospheres of his not-so-quiet familiar contests and what we now call his detective plots. If Collins set some of his fictions in Italy, which was seen by the English as the exotic homeland of passion and crime, Italian writers borrowed largely from the English settings of Victorian fictions, including Collins's. Some genres practised by late nineteenth-century writers in Italy, such as detective fiction, the psychological novel and il giallo (the thriller), drew both on English literature and true crime, deriving their settings and criminal plots from Newgate novels, Victorian police reports and sensation novels like those authored by Collins. Two cases in point are Carlo Emilio Gadda and Antonio Fogazzaro. Both writing in the late nineteenth century, Gadda and Fogazzaro acknowledged their debt to Victorian popular writers, and especially to sensation novelists like Wilkie Collins. They made large use of literary devices developed by their English predecessors, such as thrilling familiar intrigues (Gadda) and evanescent ghostly characters and secret letters (Fogazzaro), to cite only a few. In ways similar to their English fellow writers, moreover, these Italian writers aimed to arouse thrilling emotions and involve readers into exciting investigations, providing clues to dark secrets and crimes.

This long-established 'dialogue' is now further nourished by the recent Italian translation of Collins's Mr Wray's Cashbox published in December 2019 by Edizioni Croce with the title Lo scrigno di Mr Wray ovvero la maschera e il mistero. Translated by Emilia Carmen Cavaliere, with a detailed introduction by Mariaconcetta Costantini, the volume offers to the Italian public the first translation of this minor novel by Collins which is still largely unread and understudied, yet clearly deserves more attention. The quality of Cavaliere's translation is undeniable: she perfectly manages to render Collins's style and descriptions into Italian. Her skills are particularly evident in the way she reproduces the original's humour and melodrama, so typical of Collins's fiction. Generally, melodrama entails long descriptions of states of mind and psychological details that are hard to explain with few words. Considering that the Italian language usually requires lengthier phrases than English to express the same concepts, the novel's original rhythm could have easily been lost. Yet Cavaliere's translation successfully reproduces both the form and the content of the original without depriving the new text of the original's humour and pathos. Another merit of the volume is that of offering footnotes that are very explicative: they introduce the target reader to Victorian social and educational paradigms that are mostly unknown in Italy. This 
is the case of the original references to the boys" "speech day at a country school". Cavaliere does not translate "speech day" literally but opts for a clarification, rendering it as "i discorsi del giorno della premiazione" (28) and adding a footnote that explains the British educational system of the day.

The Introduction offers details about the novel's genesis and fortune, as well as its distinctive elements. Among other things, it highlights that Mr Wray's Cash-Box was not so successful among Collins's reading public, probably due to its classification as a "Christmas Book" which, written years after Dickens's launch of this subgenre, no longer satisfied the changed tastes of the Victorian middle classes, now more clearly leaning towards sensationalism. Costantini also emphasises that, despite being a Christmas story, Mr Wray's Cash-Box lacked some defining elements of the subgenre. Notably, the novel narrates no change of heart and the villains featured in it go unpunished. A flaw of the original that might also account for its lack of success is the fact that, in the Introduction to the first edition, Collins accidentally unveiled the crucial mystery of the narrative, thereby spoiling the readers' suspense. If read today, however, Mr Wray's Cash-Box appears as an important early novel, which offers an intriguing combination of various elements Collins would use in his later works. Its attention for the human psyche, its Gothic paraphernalia and its sensational details are all ingredients that the author would rework in his subsequent fictions, which would make him a successful popular novelist and an acclaimed practitioner of the sensation school for fiction. Other aspects of Mr Wray's Cash-Box usefully highlighted in the Introduction are its autobiographical elements, notably $\mathrm{Mr}$ Wray's passion for Shakespeare and his theatre (a passion that was shared by Collins's mother Harriet), its parody of cant and outward shows of religion (which is conveyed through the minor character of Colebatch), and the determination of a teenage woman (Annie) that mirrors the strength of will of Collins's mother.

Worthy of notice is also the novel's pivoting around secrets, mysteries and intrigues. These elements, which would be at the core of the sensation novel later practised by Collins, would contribute to make his fiction popular at his times and are still appealing in the new millennium. Italian readers are no exception. Like their British counterparts, they enjoy the distinctive elements of Collins's fiction a novelist that, celebrated by T. S. Eliot as the author of "the first and the greatest of English detective novels", was also famously praised by Henry James for unveiling "the mysteries which are at our own doors". These sensational and mystery elements are likely to attract the Italian reading public; yet, as observed by Pietro Citati, Collins is still "not well known in Italy" (Citati 2018) and deserves to be made more available. For example, not many Italian readers know that Collins wrote about the unconscious, which according to Citati he saw as "often provoked by opium and usually covered by social habits, much earlier than Sigmund Freud" (Citati, 2018, my translation). Collins's interest in psychological disorders and in the mysteries of the human mind is already evident in Mr Wray's Cash-Box. This is exemplified by Mr Wray's admission - reported by the character of "Julius Caesar" - that his Shakespearean passion has produced a sense of pathological disorientation: "“it (the cashbox) reminds me of that dreadful dream'. And then, sir, he told us about what had happened, just as if he really had dreamt 
it; saying he couldn't get the subject quite out of his head, the whole thing was so much as if it had truly taken place"" (67).

Another topic of Mr Wray's Cash-Box that would be further developed in later Collins novels is its characterisation of Annie Wray, an unusual heroine who displays mental strength and self-assertion despite her young age. An interesting figure for modern readers, especially in a country like Italy that is still battling to improve gender relations, Annie is an early prototype of similar female characters portrayed by Collins who, like Marion Halcombe in The Woman in White and Rachel Verinder in The Moonstone, are "women that exist in their own right as courageous, determined, generous persons" (Allen 1954: 216).

Offering Mr Wray's Cash-Box to a twenty-first-century readership means to recreate the atmosphere of mid-Victorian England, a period that experienced interesting cultural and socio-political transformations. Its pioneering use of sensationalism, its unorthodox characterisation of femininity, its attention for the obscure mechanisms of the unconscious are elements that are still supposed to attract readers, especially in a country like Italy which loves melodrama. In addition to drawing inspiration from Italian art, women and emotional diversity three elements that contributed to making his fiction sensational and to-be-readall-at-once - Collins can still fascinate the Italian public with his sensational narratives. And it is this objective that a volume like Lo scrigno di Mr Wray aims to achieve. The latest of many translations of Collins's works, Lo scrigno di $\mathrm{Mr}$ Wray invites the Italian readership to enjoy the production of a popular Victorian novelist who, among other things, was animated by a deep interest in social changes, bizarre human passions and the puzzling convolutions of the human mind.

\section{Bibliography}

Ackroyd, Peter (ed.). 2012. Wilkie Collins. A Brief Life. New York: Nan A. Talese.

Allen, Walter (ed.). 1954. The English Novel. Middlesex: Penguin Books.

Citati, Pietro. 2018. "Senza lieto fine. La Londra nera di Wilkie Collins", La Repubblica (March).

Collins, Wilkie (ed.) 2014. Mr Wray's Cash Box or the Mask and The Mistery -A Christmas Sketch. Adelaide: eBooks@ Adelaide.

Pykett, Lyn (ed.) 2005. Authors in Context: Wilkie Collins. Oxford: Oxford University Press.

\section{Recommended Citation}

Vinci, Francesca. 2020. Review of Wilkie Collins, Lo scrigno di Mr Wray, ovvero la maschera e il mistero. [Mr Wray's Cashbox] Edited with an Introduction by Mariaconcetta Costantini. Translated by Emilia Carmen Cavaliere. Rome: Libreria Croce, 2019, 192 pp. $€ 16,90$. ISBN: 88-6402-371-2 EAN: 9788864023717. Victorian Popular Fictions Journal 2.1: 123-126. DOI: https://doi.org/10.46911/BUGR7559 